\title{
ANALISIS PENGARUH PENCEGAHAN KECURANGAN AKUNTANSI TERHADAP KUALITAS LAPORAN KEUANGAN DENGAN TATA KELOLA PEMERINTAHAN DAERAH SEBAGAI VARIABEL PEMODERASI
}

\section{ANALYSIS OF THE EFFECT OF ACCOUNTING FRAUD PREVENTION ON THE QUALITY OF FINANCIAL STATEMENTS WITH GOOD GOVERNANCE OF REGIONAL AS A MODERING VARIABLE}

\author{
Tumpal Manik \\ Universitas Maritim Raja Ali Haji - Tanjungpinang \\ Email : tmanyk@gmail.com dan tmanik@umrah.ac.id
}

\begin{abstract}
ABSTRAK
Penelitian ini bertujuan untuk menguji pengaruh kecurangan akuntansi melalui kualitas SDM, sistem akuntansi keuangan daerah, Sistem pengendalian intern dan pemanfatan teknologi informasi terhadap kualitas laporan keuangan yang dimoderasi tata kelola pemerintahan di Provinsi Kepulauan Riau. Data penelitian sebanyak 250 respenden. Pengolahan hasil melalui uji asumsi klasik, uji t, uji t dan uji determinasi. Hasil penelitian menunjukkan bahwa pencegahan kecurangan akuntansi berpengaruh signifikan terhadap kualitas laporan keuangan sebesar $68 \%$. kemudian pengaruh lainnya penerapan sistem akuntansi keuangan daerah sebesar $28 \%$. sistem pengendalian intern sebesar $7,8 \%$, pemanfatan teknologi informasi sebesar $19,8 \%$. Sedangkan interaksi variabel moderasi tata kelola pemerintahan memperkuat pengaruh kualitas sdm, sistem akuntansi keuangan daerah sistem pengendalian internal terhadap kualitas laporan keuangan sebesar $68 \%$.
\end{abstract}

Kata kunci : Kecurangan akuntansi, kualitas laporan keuangan dan tata kelola

\section{ABSTRACT}

This research is aims to examine the effect of accounting fraud through the quality of human resources, regional financial accounting systems, internal control systems and utilization of information technology on the quality of financial reports that are moderated by good regional governance in the Riau Islands Province. The research data were 250 respondents. Processing the results through the classic assumption test, $t$ test, $t$ test and determination test. The results showed that the prevention of accounting fraud significantly affected the quality of financial statements by $68 \%$. then the other influence is the application of the regional financial accounting system by $28 \%$. internal control system at $7.8 \%$, information technology at $19.8 \%$. while the interaction with good governance of regional as a modering variable is strengthens to effect of quality human resources, the regional financial accounting system internal control system to the quality of financial statements by $68 \%$.

Keywords: Accounting fraud, quality of financial statements and good governance. 


\section{PENDAHULUAN}

Kecurangan akuntansi selalu menjadi isu fenomenal dan menarik untuk dibahas dengan berbagai kasus korupsi, kini tengah berkembang dalam masyarakat, yakni kecurangan dalam laporan keuangan, penyalahgunaan asset dan korupsi sering terjadi pada pemerintahan yaitu berkaitan dengan praktik korupsi. Krupsi bisa dilakukan oleh siapa saja, meskipun pelaku fraud adalah orang yang baik dan dapat dipercaya.

Indonesia merupakan korupsi dengan total kerugian negara sebesar Rp 1,47 Triliun (Indonesian Corruption Watch, 2017). Transparansi internasional dalam surveynya tahun 2016 juga menunjukkan salah satu negara Indonesia dengan tingkat korupsi yang tinggi. Data yang dihimpun oleh Indonesian Corruption Watch menunjukkan bahwa selama tahun 2016, terdapat 482 kasus bahwa Indonesia menempati peringkat 90 dari 176 negara yang diukur tingkat korupsinya skor 37.

Kasus kecurngan akuntansi yang diaporkan oleh Indonesia Corruption Watch (2018), bahawa trend penindakan kasus korupsi sejak tahun 2015-2018 terdiri dari 2.062 kasus korupsi, 12.144 orang tersangka korupsi dan kerugian negara sebesar Rp 9,168 triliun. Data Komisi Pemberantasn Korupsi (KPK) ada 104 orang kepala daerah terjerat korupsi yang telah di ditangani oleh KPK. Kasus korupsi tersebut 62 orang bupati dan 15 orang gubernur. Tahun 2018 sebanyak 456 kasus korupsi, kerugian negara 5,6 triliun, jumlah tersangka 1.087 orang, telah dilakukan KPK untuk penyelidikan sebanyak 164 perkara korupsi, Penyidikan 199 perkara korupsi, Penuntutan 151 perkara korupsi.

Berdasarkan isu kecurangan akuntasi dan kasus korupsi, beberapa hasil penelitian dalam publikasi jurnal akuntansi, mengungkapkan bahwa Keefektifan pengendalian internal, moralitas individu tidak berpengaruh terhadap kecenderungan kecurangan akuntansi Purwaningrum (2018), hal ini mendukung penelitian Naeli (2018), Hary (2017), Rahmaida (2017), Ayu (2016), Fitri (2016) dan Ahriati (2015), bahwa keefektifan pengendalian internal, ketaatan aturan akuntansi dan asimetri informasi tidak berpengaruh terhadap kecenderungan kecurangan akuntansi.

Hasil penelitian lainnya yang bertentangan dangan penelitian atas, yakni Rahmaida (2017), Agung (2017), Ayu (2016), Farizqa (2015), Vani (2013), dan Fauzi (2011), mengungkapkan bahwa Keefektifan pengendalian internal, ketaatan aturan akuntansi, asimetri informasi dan periaku tiak etis berpengaruh signifikan terhadap kecenderungan kecurangan akuntansi.

Berdasarkan analisis kejadian kasus kecurangan, teori kecenderungan kecurangan akuntansi dan hasil penelitian terdahulu belum menunjukkan hasil yang konsisten, sehingga peneliti tertarik dan ingin melakukan penelitian dengan judul "Analisis Pengaruh Pencegahan Kecurangan Akuntansi Terhadap Kualitas Laporan Keuangan dengan Tata Kelola Pemerintahan Daerah Sebagai Variabel Pemoderasi" di Provinsi Kepulauan Riau,

Penelitian ini bertujuan untuk menguji pengaruh kecurangan akuntansi terhadap kualitas laporan keuangan dengan tata kelola pemerintahan daerah sebagai variabel pemoderasi. Kecurangan akuntansi dianalisis berdasarkan kualitas SDM, sistem akuntansi keuangan daerah, Sistem pengendalian intern dan pemanfatan teknologi informasi, maka tujan penelitian adalah 1) pengaruh kualitas SDM terhadap kualitas laporan keuangan, 2) pengaruh sistem akuntansi keuangan daerah terhadap kualitas laporan keuangan, 3) pengaruh Sistem pengendalian intern terhadap kualitas laporan keuangan, 4) pengaruh pemanfatan teknologi informasi terhadap kualitas laporan keuangan, 5) secara parsial pengaruh kecurangan akuntansi terhadap kualitas laporan keuangan dengan tata kelola pemerintahan daerah sebagai variabel pemoderasi. 


\section{LANDASAN TEORI}

\section{Pencegahan Kecurangan Akuntansi}

Praktik kecurangan (fraud) selalu menjadi isu fenomenal dan menarik untuk dibahas dengan kasus-kasus yang kini tengah berkembang dalam masyarakat. Association of Certified Fraud Examiners menggolongkan fraud dalam tiga jenis, yaitu kecurangan dalam laporan keuangan, penyalahgunaan asset dan korupsi (Surjandari, 2015). Salah satu jenis fraud yang paling sering terjadi di sektor pemerintahan yaitu berkaitan dengan praktik korupsi. Korupsi berasal dari bahasa latin, corruptio corrumpere yang artinya busuk, rusak, menggoyahkan, memutarbalik atau menyogok (Permana et al. 2017).

Fraud bisa dilakukan oleh siapa saja, meskipun pelaku fraud adalah orang yang baik dan dapat dipercaya. Apabila pelaku fraud tidak segera ditindak, maka kerugian perusahaan semakin besar dan memberi cerminan yang buruk bagi karyawan lain. Kemungkinan besar suatu kecurangan terjadi ketika lingkungan pekerjaan integritasnya lemah, pengendaliannya tidak kuat, kehilangan akuntabilitas, atau mendapat tekanan yang besar, maka tidak dapat dipungkiri seseorang akan melakukan ketidakjujuran.

Pencegahan kecurangan (fraud) merupakanupaya terintegrasi yang dapat menekan, terjadinya faktor penyebab fraud. (Pusdiklatwas BPKP, 2008:37) dan Widjaja (2012:59). Pencegarahan fraud dapat dianalisis berdasarkan : (1) Budaya jujur dan etika yang tinggi: a) Menetapkan tone at the top, b) Menciptakan lingkungan kerja yang positif, c) Mempekerjakan dan mempromosikan pegawai yang tepat, d) Pelatihan, e) Konfirmasi. (2) Tanggung jawab manajemen untuk mengevaluasi pencegahan fraud: a) Identifikasi risiko kecurangan, b) Mengukur risiko kecurangan, c) Mengurangi risiko kecurangan, d) Memantau program pengendalian, (3) Pengawasan oleh komite audit : a) Pelaporan, b) Laporan periodic, c) Laporan lain.

Pencegahan kecurangan akuntansi dalam pemerintahan daerah maupun pusat dapat dianalilis berdasarkan kelengkapan elemen-elemen pengandalian dan kompetensi yang tersedia, yaitu: 1) Memiliki sumber daya manusia yang kompeten, 2) Penerapan sistem akuntansi keuangan daerah, 3) Penegasan dari pelaksana sistem pengendalian intern, 3) penggunaan teknologi informasi dan 4) tata kelola pemerintahan yang baik dan benar.

\section{Kompetensi Sumber Daya Manusia}

Kompetensi Sumber Daya Manusia (SDM) bagian dari fakor yang mempegaruhi pencegahan kecurangan akuntansi dan peningkatan kualitas laporan keuangan, khususnya pada pemerintah daerah, sebab dalam kompetensi mengandung potensi yang terkandung dalam diri manusia untuk mewujudkan peranannya sebagai manusia yang adaptif dan transformatif yang mampu mengelola dirinya sendiri serta seluruh potensi yang terkandung di alam menuju tercapainya kesejahteraan kehidupan dalam tatanan yang seimbang dan berkelanjutan. Sumber daya manusia adalah faktor penting demi terciptanya laporan keuangan yang berkualitas. Dalam hal ini kompetensi sumber daya manusia memiliki peranan yang sangat penting untuk merencanakan, melaksanakan, dan mengendalikan entitas yang bersangkutan.

Kompetensi merupakan pengetahuan dan keahlian yang dimiliki diperlukan untuk menyelesaikan tugas. Kompetensi sumber daya manusia dapat diukur dan ditingkatkan : kompetensi pemahaman tentang akuntansi, SDM yang produktif, Sumber daya yang memadai, memiliki peran dan tanggung jawab, mengikuti pelatihan keahlian dalam tugas, sosialisasi peraturan baru dan pemahaman tentang struktur organisasi, (Guy et al, 2003). Berdasarkn teori diatas, maka hipotesis yang dikembangkan adalah : 
H1: Diduga kompetensi sumber daya manusia berpengaruh terhadap peningkatan kualitas laporan keuangan pemerintah daerah.

H5: Diduga kompetensi sumber daya manusia berpengaruh terhadap kualitas laporan keuangan pemerintah daerah yang dimoderasi dengan tata kelola pemerintahan.

\section{Sistem Akuntansi Keuangan Daerah}

Badan Akuntansi Keuangan Negara (BAKUN) Departemen Keuangan RI (2001:1), Sistem akuntansi keuangan secara sederhana adalah suatu sistem informasi yang menggabungkan proses pencatatan, pengklasifikasian, pengikhtisaran, pelaporan data yang berkaitan dengan keuangan dari suatu entitas sehingga dapat menghasilkan informasi keuangan yang dapat digunakan sebagai dasar dalam pengambilan keputusan oleh pihak-pihak yang berkepentingan, yakni kesesuaian sistem dengan SAP, pengidentifikasian transaksi, pencatatan transaksi, bukti disetiap transaksi, pencatatan kronologis, pengklasifikasian transaksi, laporan keuangan setiap periode dan pelaporan yang konsisten dan periodik.

Sistem akuntansi pemerintahan dijelaskan dalam PP No.24 Tahun 2005 tentang Standar Akuntansi Pemerintahan, sistem akuntansi pemerintahan daerah adalah serangkaian prosedur manual maupun yang terkomputerisasi mulai dari pengumpulan data, pencatatan, pengikhtisaran, dan pelaporan posisi keuangan dan operasi pemerintah. Permendagri Nomor 21 Tahun 2011, bahwa sistem akuntansi pemerintahan daerah sekurang-kurangnya meliputi: prosedur akuntansi penerimaan kas, prosedur pengeluaran kas, prosedur akuntansi aset tetap/barang milik daerah, dan prosedur akuntansi selain kas.

Permendagri Nomor 64 Tahun 2013, menegaskan bahwa sitem akuntansi pemerintahan daerah memuat pilihan prosedur dan teknik akuntansi dalam melakukan identifikasi transaksi, pencatatan pada jurnal, posting kedalam buku besar, penyusunan neraca saldo serta penyajian laporan keuangan. Penyajian laporan keuangan sebagaimana dimaksud terdiri atas: a) laporan realisasi anggaran, b) laporan perubahan saldo anggaran lebih, c) neraca, d) laporan operasional, e) laporan arus kas, f) laporan perubahan ekuitas, dan g) catatan atas laporan keuangan. Berdasarkn teori diatas, maka hipotesis yang dikembangkan adalah:

H2: Diduga sistem akuntansi keuangan daerah berpengaruh terhadap peningkatan kualitas laporan keuangan pemerintah daerah.

H6: Diduga sistem akuntansi keuangan daerah berpengaruh terhadap kualitas laporan keuangan pemerintah daerah yang dimoderasi dengan tata kelola pemerintahan.

\section{Sistem Pengendalian Intern}

Pengendalian internal yang terdapat dalam sebuah instansi atau organisasi tidak hanya mencakup kegiatan akuntansi dan keuangan saja tetapi meliputi segala aspek kegiatan organisasi tersebut. Tuanakotta (2014), menyatakan bahwa pengendalian internal merupakan langkah awal dalam pencegahan fraud. Pencegahan fraud pada umumnya adalah aktivitas yang dilaksanakan dalam halpenetapan kebijakan, sistem dan prosedur yang membantu bahwa tindakan yang diperlukan sudah dilakukan dewan komisaris, manajemen dan personil lain dalam perusahaan/organisasi untuk dapat memberikan keyakinan memadai dalam mencapai tujuan organisasiyaitu: efektivitas dan efisiensi operasi, keandalan laporan keuangan, dan kepatuhan terhadap hukum dan peraturan yang berlaku.

Implementasi PP No 60, menegaskan dalam SPI wajib didukung dengan dokumen dan catatan yang memadai, pemisahan wewenang, tindakan disiplin atas pelanggaran. Sistem pengendalian intern merupakan suatu cara untuk mengarahkan, mengawasi, dan mengukur sumber daya suatu organisasi, serta berperan penting dalam pencegahan dan pendeteksian 
penggelapan (fraud). Pengendalian intern terdiri atas kebijakan dan prosedur yang digunakan dalam mencapai sasaran dan menjamin atau menyediakan informasi keuangan yang andal, serta menjamin ditaatinya hukum dan peraturan yang berlaku.

Fadilah (2011), menyatakan bahwa sistem pengendalian internal memiliki pengaruh langsung terhadap Good Governance sehingga berimplikasi terhadap pencegahan fraud. Namun, sistem pengendalian internal tidak luput dari kelemahannya, kelemahan ini dapat dimanfaatkan oleh oknum pelaku kecurangan (Martani dan Zaelani, 2011). Jika kelemahan sistem ini didukung oleh moralitas aparatur yang baik, maka segala jenis kecurangan dapat dicegah. Sistem Pengendalian Intern Pemerintah ini bertujuan memberikan keyakinan memadai atas tercapainya tujuan organisasi. Pemberian keyakinan tersebut dicapai melalui tahapan kegiatan yang lebih efektif dan lebih efisien, keandalan pelaporan keuangan, pengamanan aset negara, dan ketaatan terhadap seluruh peraturan perundang-undangan. Berdasarkn teori diatas, maka hipotesis yang dikembangkan adalah :

H3 : Diduga sistem pengendalian intern berpengaruh terhadap peningkatan kualitas laporan keuangan pemerintah daerah.

$\mathrm{H} 7$ : Diduga sistem pengendalian intern berpengaruh terhadap kualitas laporan keuangan pemerintah daerah yang dimoderasi dengan tata kelola pemerintahan.

\section{Pemanfaatan Teknologi Informasi}

Pemanfaatan teknologi informasi merupakan penggunaan secara optimal dari perangkat keras komputer, perangkat lunak (software), database, jaringan (internet, intranet) dan jenis lainnya yang berhubungan dengan teknologi. Pemanfaatan teknologi informasi mencakup adanya pengolahan data, pengolahan informasi, sistem manajemen informasi, proses kerja secara elektronik dan pemanfaatan teknologi informasi yang dapat diakses secara mudah oleh masyarakat.

Keputusan dari hasil pemrosesan teknologi komputer ke dalam sistem informasi akuntansi keuangan, telah mengubah cara kerja para pegawai pada posisi keuangan dan akuntansi, yaitu dalam penyimpanan data, pengambilan kembali data, dan pengendalian hanya melalui komputer. Data yang tersimpan dalam komputer akan memudahkan proses audit teknologi informasi (audit electronic data processing), dimana proses audit electronic data processing terdapat tiga cara melaksanakan audit dengan komputer antara lain: pengujian pemroses data sistem komputer klien sebagai bagian pengendalian, menguji pembukuan yang direcord dalam komputer untuk melakukan verifikasi laporan keuangan, pengujian komputer beradasarkan tugas dari catatan transaksi yang terpisah (Manik, 2018). Berdasarkn teori diatas, maka hipotesis yang dikembangkan adalah :

H4: Diduga pemanfaatan teknologi informasi berpengaruh terhadap peningkatan kualitas laporan keuangan pemerintah daerah.

H8 : Diduga pemanfaatan teknologi informasi berpengaruh terhadap kualitas laporan keuangan pemerintah daerah yang dimoderasi dengan tata kelola pemerintahan.

\section{Kualitas Laporan Keuangan dan Tata Kelola Pemerintahan}

Reformasi dibidang keuangan negara telah dilaksanakan melalui paket UndangUndang yang terdiri dari Undang-Undang Nomor 17 Tahun 2003 tentang Keuangan Negara, Undangundang Nomor 1 Tahun 2004 tentang Perbendaharaan Negara dan Undang-undang Nomor 15 Tahun 2004 tentang Pemeriksaan Pengelolaan dan Tanggungjawab Keuangan Negara. Ketiganya merupakan landasan dan pedoman agar keuangan negara dapat dikelola secara tertib, ekonomis, efisien, efektif, transparan dan bertanggung jawab dengan memperhatikan rasa 
keadilan dan kepatutan. Sejalan dengan tujuan tersebut, Undang-Undang nomor 28 tahun 2009 mengamanatkan untuk mewujudkan penyelenggaraan negara yang bebas dan bersih dari korupsi, kolusi dan nepotisme.

Standar Akuntansi Pemerintah (SAP) PP Tahun 2010 menyatakan karakteristik kualitatif laporan keuangan keuangan adalah ukuran-ukuran normatif yang perlu diwujudkan dalam informasi akuntansi sehingga dapat memenuhi tujuan. Keempat karakteristik tersebut merupakan persyaratan normatif yaitu relevan, andal, dapat dibandingkan dan dapat dipahami. Selain adanya SAP sebagai pedoman dalam proses penyusunan laporan keuangan daerah, proses penyusunan laporan keuangan juga harus dilakukan secara efektif dan efisien, tepat waktu serta data-data yang dihasilkan dari laporan keuangan tersebut harus akurat, sesuai dengan prinsip akuntansi pemerintah.

Pemerintah sebagai pengemban amanat dari rakyat mempunyai kewajiban untuk melaksanakan tugasnya secara efektif dan efisien, salah satunya adalah mengelola keuangan negara dengan baik dan accountable. Namun, pada pelaksanaannya banyak praktik kecurangan yang berdampak negatif pada sektor ekonomi maupun sosial (Lediastuti, 2014). Salah satu indikator terjadinya permasalahan dalam pengelolaan keuangan instansi pemerintah juga dapat dilihat dari hasil pemeriksaan Badan Pemeriksa Keuangan terhadap laporan keuangan.

Kualitas laporan keuangan pemerintahan sanagat berkaitan dengan tata kelolah pemerintah, sebab suatu negara telah mencapai tata kelola yang baik apabila telah berhasil menyelenggarakan sistem pengaturan pembangunan negara yang kuat, serta bertanggung jawab, dengan tetap beriringan dengan prinsip demokrasi dan prinsip pasar yang efisien. Di samping itu, dalam tata kelola pemerintah yang baik akan menghindari kesalahan dalam alokasi dana pembangunan. Termasuk penanggulangan dini tindak pidana korupsi. Tata kelola pemerintah juga akan menjalankan anggaran secara disiplin sehingga aktivitas usaha rakyat dapat tumbuh dengan baik. Tata kelola pemerintahan yang baik sebagai suatu tanggung jawab dari kewenangan ekonomi, kewenangan administrasi, dan kewenangan politik untuk mengatur masalah-masalah sosial dalam suatu negara/pemerintahan dalam meningkatkan kesajahteraan masyarakat melalui pengukuran: kepastian hukum dan rasa keadilan, partisipatif, responsive, transparansi, akuntabilitas, koordinasi dan mempunyai visi strategis untuk pemerintahan.

\section{METODOLOGI PENELITIAN}

\section{Jenis dan Lokasi Penelitian}

Jenis penelitian ini menggunakan metode kuantitatif, yakni pengumpulan data dilakukan dengan menggunakan serangkaian instrumen penelitian berupa kuesioner. Data yang terkumpul kemudian dikonversikan menggunakan kategori/kriteria yang sudah ditetapkan sebelumnya sebagai responden penelitian untuk membuktikan sumber data faktor-faktor yang mempengaruhi pencegahan kecurangan akuntansi terhadap kualitas laporan keuangan pemerintah daerah.

\section{Lokasi Tempat Penelitian}

Lokasi penelitian diakukan di Provinsi Kepulauan Riau sebagai salah satu wilayah pemerintah daerah yang menggunakan anggaran pemerintah, serta sebagai pusat alokasi anggaran pemerintahan kota maupun kabupaten di Provinsi Kepulauan Riau sesuai dengan objek pengamatan penelitian.

\section{Populasi, Sampel dan Data}

Populasi dalam penelitian ini pada Satuan Kerja Perangkat Daerah (SKPD) atau sekarang disebut Organisasi Perangkat Daerah (OPD) yaitu pengelola unit kerja bagian keuangan, 
bendahara dan bagian akuntansi juga pejabat struktural pada satuan kerja perangkat daerah Provinsi Kepulauan Riau. Populasi penelitian ini memiliki kriteria untuk pengambilan sampel yakni hanya pada Kantor Dinas/Badan (SKPD/OPD) yang memiliki anggaran > 20 miliar, maka jumlah sampel sebanyak 250 orang respenden dan menjadi data penelitian.

\section{Teknik Pengumpulan Data}

Teknik pengumpulan data, antara lain; 1) Observasi; mengukur sikap dari responden (wawancara dan angket) untuk merekam berbagai fenomena yang terjadi (situasi, kondisi). Dalam observasi ini, peneliti secara langsung terlibat dalam kegiatan sehari-hari orang atau situasi yang diamati sebagai sumber data, 2) Angket/kuisioner; dilakukan dengan cara memberikan seperangkat pertanyaan atau pernyataan kepada orang lain yang dijadikan responden untuk dijawab, tujuan pertanyaan yang diberikan kepada responden untuk menggali data sesuai dengan rumusan masalah dan tujuan penelitian, 3) Wawancara; dilakukan melalui tatap muka dan tanyajawab langsung antara pengumpul data maupun peneliti terhadap narasumber atau sumber data.

\section{Variabel Penelitian dan Definisi Operasional Variabel}

Penelitian ini menggunakan tiga bentuk variabel penelitian, antara lain: 1) Variabel Independen Pencegahan Kecurangan Akuntansi dianalisis berdasarkan Kompetensi Sumber Daya Manusia (X1), Sistem Akuntansi Keuangan Daerah (X2), Pengendalian Internal (X3) dan Pemanfatan Teknologi Informasi (X4). Variabel dependen yaitu Kualitas Laporan Keuangan (Y) dan Variabel Pemoderasi yakni Tata Pemerintahan (Z). Variabel diukur dengan model skala Likert lima poin, yaitu Sangat Tidak Setuju skor 1, Tidak Setuju skor 2, Ragu-Ragu skor 3, Setuju skor 3, dan Sangat Setuju skor 5. Responden diminta untuk menyatakan terhadap pertanyaan sesuai dengan kondisi mereka yang sesungguhnya.

\section{Variabel Terikat (Dependent Variable)}

Variabel terikat $(Y)$ dalam penelitin ini adalah Kualitas laporan keuangan, Penelitian ini ingin mengetahui kualitas laporan keuangan sesauai dengan penggunaan pagu anggaran. Indikator variabel terikat (kualitas laporan keuangan) terdiri dari; 1) Mengunakan acuan standar akuntansi pemerintah daerah, 2) Laporan keuangan disajikan dengan andal dan dapat dipercaya, 3) Informasi laporan keuangan yang disajikan dapat dipahami dan jelas, 4) Informasi dalam laporan keuangan dapat dibandingkan, 5) pedoman penyusunan LKPD, 6) Laporan keungan yang transparan dan bertanggungjawab, 7) taat pada peraturan perundang-undangan dan 8) tepat waktu untuk penetapan perda APBD.

\section{Variabel Pemoderasi (Moderating Variable)}

Variabel pemoderasi (Z) mengunakan tata kelola pemerintahan. Tata kelola pemerintahan yang baik sebagai suatu tanggung jawab dari kewenangan ekonomi, kewenangan administrasi, dan kewenangan politik untuk mengatur masalah-masalah sosial dalam suatu negara/pemerintahan dalam meningkatkan kesajahteraan masyarakat. Indikator pengukuran: 1) rule of law (kepastian hukum dan rasa keadilan), 2) partisipatif, 3) responsive, 4) transparansi, 5) akuntabilitas, 6) koordinasi, 7) mempunyai visi strategis

\section{Variabel Bebas (Independent Variable)}

Variabel independent menggunakan Pencegahan Kecurangan Akuntansi dianalisis berdasarkan; 1) Kompetensi Sumber Daya Manusia, 2) Sistem Akuntansi Keuangan Daerah, 3) Sistem Pengendalian Internal, 4) Pemanfatan Teknologi Informasi. 
1) Kompetensi Sumber Daya Manusia (SDM) merupakan potensi yang terkandung dalam diri manusia untuk mewujudkan peranannya sebagai manusia yang adaptif dan transformatif yang mampu mengelola dirinya sendiri serta seluruh potensi yang terkandung menuju tercapainya kesejahteraan kehidupan dalam tatanan yang seimbang dan berkelanjutan. Indikator kompetensi SDM; 1) latar belakang pendidikan bagian keuangan dan akuntansi, 2) memahami standar akuntansi pemerintahan, 3) menyelesaikan tugas tepat waktu, 4) kesalahan laporan yang dilakukan seorang pegawai, 5) pelatihan, 6) sosialisasi tentang UU, 7) Menyampaikan laporan keuangan tepat waktu.

2) Sistem Akuntansi Keuangan Daerah; sistem informasi yang menggabungkan proses pencatatan, pengklasifikasian, pengikhtisaran, pelaporan data yang berkaitan dengan keuangan. Indikator sistem akuntansi keuangan daerah terdiri dari; 1) laporan keuangan disusun/disajikan sebagai bentuk pertanggungjawaban, 2) pengguna laporan keuangan untuk mengevaluasi pelaksanaan kegiatan suatu entitas, 3) informasi keuangan yang terbuka dan jujur, 4) kecukupan penerimaan pada periode pelaporan, 5) laporan keuangan dapat menilai derajat pencapaian.

3) Sistem Pengendalian Intern (SPI); untuk mengarahkan, mengawasi, dan mengukur sumber daya suatu organisasi, serta berperan penting dalam pencegahan dan pendeteksian penggelapan (fraud). Indikator SPI terdiri dari; 1) Integritas data dan dokumen tersimpan dengan baik, 2) mencatat transaksi keuangan dengan memposting secara tepat, 3) transaksi tidak dapat dilakukan tanpa adanya otorisasi dari pihak yang berwenang, 4) kualitas personal bagian pengendalian internal, 5) struktur organisasi dan uraian tugas, 6) pembagian tanggungjawab yang jelas, 7) otorisasi transaksi, 8) peraturan untuk pemantauan, evaluasi aktivitas operasional.

4) Pemanfaatan Teknologi Informasi; merupakan penggunaan secara optimal dari komputer, perangkat keras dan lunak (software), database, jaringan (internet, intranet), electronic commerce. Indikator pemanfaatan teknologi informasi terdiri dari; 1) informasi yang terintegrasi lebih cepat dan akurat, 2) jaringan internet penghubung dalam pengiriman informasi, 3) pelaporan dilakukan secara komputerisasi, 4) memiliki komputer yang cukup, 5) jadwal pemeliharaan peralatan secara teratur dan tepat.

\section{Pengolahan Data dan Pengujian Penelitian}

Salah satu syarat untuk bisa menggunakan persamaan regresi berganda adalah terpenuhinya uji asumsi klasik. Empat uji asumsi klasik dalam penelitian ini meliputi normalitas, asumsi heteroskedastisitas, autokorelasi dan multikolinearitas. Kemudian pengujian hipotesis dan uji varibel pemoderasi melalui uji-t, uji-f dan uji determinasi.

\section{HASIL DAN PEMBAHASAN}

\section{Hasil Pengujian Secara Simultan dan Parsial}

Pengujian secara simultan (uji-t), uji parsial (uji-f) dan uji determinasi (D2) variable kompetensi sumber daya manusia, sistem akuntansi keuangan daerah, pengendalian intern dan pemanfatan teknologi informasi terhadap kualitas laporan keuangan ditunjukkan dalam tabel 1 dibawah ini. 
Tabel 1. Hasil Pengujian Secara Parsial dan Simultan

\begin{tabular}{lccrr}
\hline Variable & $\begin{array}{c}\text { Unstandardized } \\
\text { Coefficients }\end{array}$ & $\begin{array}{c}\text { Standardized } \\
\text { Coefficients }\end{array}$ & T-Test & $\begin{array}{r}\text { Probabilitas } \\
\text { (Sig. a 0,05) }\end{array}$ \\
\hline (Constant) & -2.539 & & -1.613 & 0,108 \\
\hline Kompetensi SDM & 0,074 & 0,058 & 1.597 & 0,111 \\
\hline SA. Keuangan Daerah & 0,280 & 0,424 & 11.566 & 0,000 \\
\hline Sistem Pengend. Intern & 0,078 & 0,079 & 2.090 & 0,038 \\
\hline Pengembangan TI & 0,191 & 0,211 & 4.313 & 0,000 \\
\hline T.Kelola Pemerintahan & 0,490 & 0,473 & 9.863 & 0,000 \\
\hline R Square & & & & 0,686 \\
Adjusted R Square & & & & 0,680 \\
F -Test & & & & 106.596 \\
Probability & & & & 0,000 \\
\hline
\end{tabular}

a. Dependent Variable: Kualitas Laporan Keuangan

Sumber data kuesioner, diolah dengan aplikasi SPSS V.24, (2019)

Tabel.1 Hasil pengujian hipotesis secara parsial dan simultan diatas menunjukkan bahwa beberapa variabel independen berpengaruah signifikan terhadap variabel kualitas laporan keuangan, dan hasil pengujian diformulasikan dalam regresi berganda secara parsial sebagai berikut :

\section{$Y=\beta 0+\beta 1 \mathrm{KSDM}+\beta 2$ SAKD $+\beta 3 \mathrm{SPI}+\beta 4 \mathrm{PTI}+\beta 5 \mathrm{TKP}+\varepsilon$ $Y=-2.539+0,074$ KSDM + 0,280 SAKD + 0,078 SPI + 0,490 PTI + 0,490 TKP + $\varepsilon$}

Keterangan ;

$Y=$ Kualitas Laporan Keuangan

KSDM = Kompetensi Sumber Daya Manusia;

$S A K D=$ Sistem Akuntansi Keuangan Daerah

SPI = Sistem Pengend. Intern

PTI = Pemanfatan Teknologi Informasi

TKP = Tata Kelola Pemerintahan

$\varepsilon=$ Error (5\%), dengan tingkat kepercayaan $95 \%$

Interpretasi hasil penelitian berdasarkan output pengolahan data statistik dalam tabel 1 dengan aplikasi SPSS V.24 adalah sebagai berikut:

KSDM Kualitas sumber daya manusia memberikan koefisien parameter 0,005 dengan tingkat signifikansi (a.0,05) yakni 0,111 >0,05, hipotesis menunjukkan bahwa kompetensi sumber daya manusia tidak berpengaruh signifikan terhadap kualitas laporan keuangan. Hal ini tidak berpengaruh karena keterbatasan sumber daya manusia yang memiliki kompetensi dan kualifikasi bidang akuntansi pemerintahan, belum memadai dan sehingga belum menunjukkan pengaruh terhadap kualitas laporan keuangan.

SAKD Penerapan standar akuntansi keuangan daerah berpengaruh signifikan terhadap kualitas laporan keuangan, pada tingkat $0,05(0,000<0,05$, tingkat kepercayaan 95\%), artinya setiap peningkatan penggunaan/penerapan standar akuntansi keuangan daerah 
dalam menyusun laporan keuangan pemerintahan daerah akan meningkatkan kualitas laporan keuangan sebesar 0,280 atau $28 \%$.

SPI Sistem pengendalian intern berpengaruh signifikan terhadap kualitas laporan keuangan, pada tingkat $0,05(0,038<0,05$, tingkat kepercayaan $95 \%)$, artinya setiap penerapan sistem pengendalian internal semakin baik dalam penggunaan anggaran pemerintahan daerah akan meningkatkan kualitas laporan keuangan sebesar 0,078 atau $7,8 \%$.

PTI Pemanfatan teknologi informasi berpengaruh signifikan terhadap kualitas laporan keuangan, pada tingkat 0,05 $(0,000<0,05$, tingkat kepercayaan $95 \%)$, artinya setiap peningkatan penggunaan dan pemanfatan teknologi informasi semakin baik dalam menyusun informasi dan melaporkan laporan keuangan atas pencatatan akuntansi pemerintahan akan meningkatkan kualitas laporan keuangan sebesar 0,191 atau $19,8 \%$.

TKP Tata kelola pemerintahan berpengaruh signifikan terhadap kualitas laporan keuangan, pada tingkat $0,05(0,000<0,05$, tingkat kepercayaan $95 \%)$, artinya setiap peningkatan dan transparansi pelaksanaan tata kelola pemerintahan akan meningkatkan kualitas laporan keuangan sebesar 0,490 atau 49\%.

Pengujian hipotesis secara simultan (uji-f) variabel pencegahan kecurangan akuntansi terdiri dari: kompetensi sumber daya manusia, sistem akuntansi keuangan daerah, pengendalian intern dan pemanfatan teknologi informasi) berpengaruh signifikan terhadap kualitas laporan keuangan pada tingkat $0,05(0,000<0,05$, tingkat kepercayaan $95 \%)$, dengan nilai adjust $\mathrm{R}$ Square sebesar 0,680 . Artinya secara simultan memiliki pengaruh sebesar $68 \%$ terhadap kualitas laporan keuangan, sedangan pengaruh lainnya $32 \%$ diluar variabel penelitian ini.

\section{Hasil Pengujian Variabel Pemoderasi}

Variabel moderasi (Z) menggunakan tata kelola pemerintahan (TKLP), Hasil pengujian variabel moderasi yaitu pengaruh kompetensi sumber daya manusia, sistem akuntansi keuangan daerah, pengendalian intern dan pemanfatan teknologi informasi terhadap kualitas laporan keuangan yang di moderasi tata kelola pemerintahan di uraikan dalam tabel 2 dibawah ini

Tabel 2. Hasil Pengujian Variabel Pemoderasi (Z)

\begin{tabular}{lccrc}
\hline Variable & $\begin{array}{c}\text { Unstandardized } \\
\text { Coefficients }\end{array}$ & $\begin{array}{c}\text { Standardized } \\
\text { Coefficients }\end{array}$ & T-Test & $\begin{array}{r}\text { Probabilitas } \\
\text { (Sig. a 0,05) }\end{array}$ \\
\hline (Constant) & 9.958 & & 12.800 & 0,000 \\
\hline Z1 (KSDM x TKP) & 0,003 & 0,099 & 2.098 & 0,037 \\
\hline Z2 (PSAP x TKP) & 0,011 & 0,518 & 12.134 & 0,000 \\
\hline Z3 (SPI x TKP) & 0,004 & 0,136 & 2.812 & 0,005 \\
\hline Z4 (PTI x TKP) & 0,006 & 0,251 & 4.721 & 0,000 \\
\hline R Square & & & & 0,693 \\
Adjusted R Square & & & & 0,688 \\
F -Test & & & & 238,205 \\
Probability & & & & 0,000 \\
\hline
\end{tabular}

a. Dependent Variable: Kualitas Laporan Keuangan

b. Moderating Variable: Tata Kelola Pemerintahan

Sumber data kuesoiner, diolah dengan aplikasi SPSS V.24, (2019) 
Tabel.2 diatas menunjukkan hasil pengujian pemoderasi tata kelola pemerintahan (Z) terhadap kualitas laporan keuangan dapat disusun formulasinya dalam regresi berganda sebagai berikut :

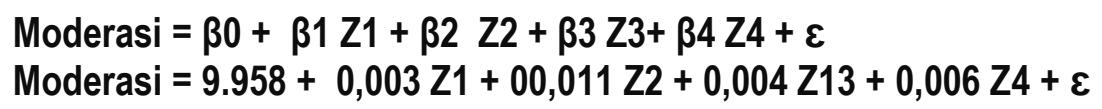

Keterangan

$\mathrm{Z1}=$ Interaksi varibel moderasi ke-1 (KSDM $\times$ TKP)

$\mathrm{Z2}=$ Interaksi varibel moderasi ke-2 (PSAP $\times$ TKP)

$\mathrm{Z3}=$ Interaksi varibel moderasi ke-3 (SPI $\times$ TKP)

Z4 = Interaksi varibel moderasi ke-4 (PTI $\times$ TKP)

Interpretasi hasil pengujian variable pemoderasi tata kelola pemerintahan $(Z)$ :

Z1 Variabel Moderasi ke-1 (KSDM x TKP) memiliki koefisien parameter 0,003 berpengaruh signifikan terhadap kualitas laporan keuangan, pada tingkat $0,05(0,037>0,05$, tingkat kepercayaan 95\%), artinya interaksi variabel moderasi (Z1) memiliki pengaruh terhadap kualitas laporan keuangan, interaksi variabel moderasi disebut sebagai Quasi Moderator, sehingga disimpulkan bahwa tata kelola pemerintahan daerah memperkuat pengaruh kualitas SDM terhadap kualitas laporan keuangan sebesar 0,003 atau 3\%.

Z2 Variabel Moderasi ke-2 (PSAP $x$ TKP) memiliki koefisien parameter 0,011 dan berpengaruh signifikan terhadap kualitas laporan keuangan, pada tingkat 0,05 (0,000 > 0,05, tingkat kepercayaan 95\%), artinya interaksi variabel moderasi (Z2) memiliki pengaruh terhadap kualitas laporan keuangan, interaksi variabel moderasi disebut sebagai Quasi Moderator, sehingga disimpulkan bahwa tata kelola pemerintahan daerah memperkuat pengaruh Sistem Akuntansi Keuangan Daerah terhadap kualitas laporan keuangan sebesar 0,011 atau $1 \%$.

Z3 Variabel Moderasi ke-3 (SPI x TKP) memiliki koefisien parameter 0,004 dan berpengaruh signifikan terhadap kualitas laporan keuangan, pada tingkat $0,05(0,001>0,05$, tingkat kepercayaan 95\%), artinya interaksi variabel moderasi (Z3) memiliki pengaruh terhadap kualitas laporan keuangan, interaksi variabel moderasi disebut sebagai Quasi Moderator, sehingga disimpulkan bahwa tata kelola pemerintahan daerah memperkuat pengaruh sistem pengendalian internal terhadap kualitas laporan keuangan sebesar 0,004 atau $0,4 \%$.

Z4 Variabel Moderasi ke-4 (PTI x TKP) memiliki koefisien parameter 0,006 dan berpengaruh signifikan terhadap kualitas laporan keuangan, pada tingkat $0,05(0,000>0,05$, tingkat kepercayaan 95\%), artinya interaksi variabel moderasi (Z4) memiliki pengaruh terhadap kualitas laporan keuangan, interaksi variabel moderasi disebut sebagai Quasi Moderator, sehingga disimpulkan bahwa tata kelola pemerintahan daerah memperkuat pengaruh pemanfatan teknologi informasi terhadap kualitas laporan keuangan sebesar 0,006 atau $0,6 \%$. 


\section{REKOMENDASI DAN KEBIJAKAN}

Berdasarkan hasil penelitian dengan interpretasi, maka peneliti memberikan rekomendasi, dari hasil penelitian menunjukkan; bahwa pengendalian kecurangan akuntansi berpengaruh sinifikan terhadap kualitas laporan keuangan dibuktikan dari a) Penerapan sistem akuntansi keuangan daerah berpengaruh signifikan terhadap kualitas laporan keuangan sebesar 28\%. b) Sistem pengendalian intern berpengaruh signifikan terhadap kualitas laporan keuangan sebesar $7,8 \%$, c) Pemanfatan teknologi informasi berpengaruh signifikan terhadap kualitas laporan keuangan, sebesar 19,8\%, 4) Tata kelola pemerintahan berpengaruh signifikan terhadap kualitas laporan keuangan, sebesar $49 \%$. Pengujian secara simultan bahwa pencegahan kecurangan akuntansi berpengaruh signifikan terhadap kualitas laporan keuangan sebesar $68 \%$.

Pengujian variable pemoderasi menunjukkan bahawa interaksi variabel moderasi disebut sebagai Quasi Moderator a) tata kelola pemerintahan daerah memperkuat pengaruh kualitas SDM terhadap kualitas laporan keuangan sebesar 3\%, b) tata kelola pemerintahan daerah memperkuat pengaruh Sistem Akuntansi Keuangan Daerah terhadap kualitas laporan keuangan sebesar $1 \%, c)$ tata kelola pemerintahan daerah memperkuat pengaruh sistem pengendalian internal terhadap kualitas laporan keuangan sebesar 0,4\%, d) tata kelola pemerintahan daerah memperkuat pengaruh pemanfatan teknologi informasi terhadap kualitas laporan keuangan sebesar $0,6 \%$.

\section{DAFTAR PUSTAKA}

Agung, Anak K, Finty Udayani dan Maria. Ratna Sari. (2017), Pengaruh Pengendalian Internal Dan Moralitas Individu Pada Kecenderungan Kecurangan Akuntansi. E-Jurnal Akuntansi Universitas Udayana Vol.18.3. Hal. 1774-1799.

Ahriati Deni, Prayitno Basuki., dan Erna Widiastuty. (2015), Analisis Pengaruh Sistem Pengendalian Internal, Asimetri Informasi, Perilaku Tidak Etis Dan Kesesuaian Kompensasi Terhadap Kecenderungan Kecurangan Akuntansi Pada Pemerintah Daerah Kabupaten Lombok Timur. Jurnal InFestasi Vol. 11, No.1, Juni 2015.

Widjaja, Amin Tunggal. (2012), Audit kecurangan dan akuntansi forensik, Harvarindo

Association of Certified Fraud Examiners. (2006), Report to Nation on Occupational Fraud \& Abuse. The Association of Certified Fraud Examiners, Inc.

Ayu, Gusti Ketut dan Rencana Sari Dewi. (2016), Pengaruh Moralitas Individu Dan Pengendalian Internal Pada Kecurangan Akuntansi (Studi Eksperimen Pada Pemerintah Daerah Provinsi Bali) Jurnal IImiah Akuntansi • Vol. 1, No. 1, Hal: 77-92. Universitas Pendidikan Ganesha

Badan Akuntansi Keuangan Negara (BAKUN) Departemen Keuangan RI. (2001:1), Tentang Sistem Akuntansi Keuangan. Jakarta.

Fadilah, Sri. (2011), Pengaruh Implementasi Pengendalian Internal dan Komitmen Organisasi dalam Pencegahan Fraud Pengadaan Barang (Survey pada 5 Rumah Sakit di Bandung). Universitas Widyatama Bandung.

Fitri, Yulita. (2016), Pengaruh Keefektifan Sistem Pengendalian Internal, Ketaatan Akuntansi, Asimteri Informasi dan Moralitas Individu Terhadap Kecendrungan Kecurangan Akuntansi Dengan Perilaku Tidak Etis Sebagai Variabel Intervening (Studi Empiris Pada Satuan Kerja Perangkat Daerah Provinsi Riau). 
Guy, D. M. et al. Penerjemah: Paul A Rajoe., dkk (2003), Edisi kelima. Auditing Jilid kedua. Jakarta: Erlangga.

Indonesian Corruption Watch. (2017), Laporan Pengendalian Intern dan Total Quality Management Terhadap Penerapan Good Governance (Studi pada Lembaga Amil Zakat Seluruh Indonesia). Simposium Nasional Akuntansi XIV. Universitas Syiah Kuala, Banda Aceh.

Indonesian Corruption Watch. (2018), Pengendalian Intern dan Total Quality Management Terhadap Penerapan Good Governance (Studi pada Lembaga Amil

Hermiyetti. (2008), Pengaruh PenerapanPengendalian Internal terhadap Pencegahan Fraud Pengadaan Barang. STEKPI Jakarta.

Implementasi Peraturan Pemerintah (PP), Nomor 60 Tahun 2008, Tentang Sistem Pengendalian Intern Pemerintah

Pusdiklatwas BPKP, (2008). Etika dalam Fraud Audit

Lediastuti, D., dan U. Subandijo. (2014), Audit Forensik Terhadap Pengelolaan dan Pertanggungjawaban Keuangan Negara (Studi Kasus pada Badan Pemeriksa Keuangan RI). e-Journal Magister Akuntasi Trisakti Volume 1 No.1: 89-108

Manik, Tumpal. (2018), Analisis Peranan Sistem Informasi Akuntansi Dalam E-Commerces Terhadap Pengendalian Bisnis Online, Jurnal IImiah Akuntansi dan Finansial Indonesia Volume 1, No.2, April Hal. 51- 64, Fakultas Ekonomi Universitas Maritim Raja Ali Haji, Tanjungpinang

Martani, Dwi., \& Fazri Zaelani. (2011), Pengaruh Ukuran, Pertumbuhan, dan Kompleksitas terhadapPengendalian Intern Pemerintah Daerah (Studi Kasus di Indonesia). Simposium Nasional Akuntansi XIV. Universitas Syiah Kuala, Banda Aceh.

Peraturan Pemerintah (PP) No. 24 Tahun 2005 tentang Standar Akuntansi Pemerintahan

Peraturan Menteri Dalam Negeri (Permendagri) No.21 Tahun 2011 Tentang Perubahan kedua Atas Peraturan Menteri Dalam Negeri Nomor 13 Tahun 2006 TentangPedoman Pengelolaan Keuangan Daerah.

Peraturan Menteri Dalam Negeri (Permendagri) No.64 Tahun 2013, Penerapan Standar Akuntansi Pemerintahan Berbasis Akrual Pada Pemerintah Daerah

Permana, BA., HD. Perdana., dan L. Kurniasih. (2017), Determinant of Fraud in Government Agency: Empirical Study at The Finance And Development Supervisory Agency (BPKP) Of Jakarta Representative Office. Asia Pasific Fraud Journal Volume 2 No.1: 93-108. doi:10.21532/apfj.001.17.02.01.08.

Purwaningrum, Diah. (2018), Pengaruh Keefektifan Pengendalian Internal, Ketaatan Aturan Akuntansi, Kesesuaian Kompensasi, Asimetri Informasi, Moralitas Individu Dan Kepuasan Kerja Terhadap Kecenderungan Kecurangan Akuntansi Dengan Perilaku Tidak Etis Sebagai Variabel Intervening (Studi Empiris Pada Organisasi Perangkat Daerah di Kabupaten Kudus), Fakultas Ekonomi, Prodi Akuntansi.

Surjandari, DA., dan I. Martaningtyas. (2015), An Empirical Study: The Effect of Performance Incentives, Internal Control System, Organizational Culture, on Fraud of Indonesia Government Officer. Mediterranian Journal of Social Sciences, Volume 6 No.5: 71-76.doi: 10.5901/mjss.2015.v6n5s5p71

Tuanakotta, Theodorus M. (2014), Mendeteksi Manipulasi Laporan Keuangan, Penerbit: Salemba Empat: Jakarta

Undang-Undang Nomor 17 Tahun 2003 tentang Keuangan Negara 
Analisis Pengaruh Pencegahan Kecurangan Akuntansi Terhadap Kualitas Laporan Keuangan Dengan Tata Kelola Pemerintahan Daerah Sebagai Variabel Pemoderasi

Undang-undang Nomor 1 Tahun 2004 tentang Perbendaharaan Negara dan Undang-undang Nomor 15 Tahun 2004 tentang Pemeriksaan Pengelolaan dan Tanggungjawab Keuangan Negara. 